\title{
Tranparansi dan Akuntabilitas Pengelolaan Dana Desa dalam Pencapaian Good Governance: Studi Kasus Desa Cepogo, Kabupaten Boyolali
}

\author{
Puji Astuti \\ Rochmi Widayanti \\ Ratna Damayanti \\ Manajemen, Universitas Islam Batik Surakarta, Indonesia \\ Korespondensi penulis: putjiastuti1703@gmail.com
}

\begin{abstract}
A village fund program is a form of government concern for the development of rural areas. The management of village funds consists of five stages, namely planning, implementation, managing, reporting, and responsibility, which should be based on the principles of good governance. The Cepogo Village Government, Cepogo District, Boyolali Regency, in Central Java Province is one of the village governments in Indonesia that has implemented the principles of good governance in managing village funds. This study aims to see how the implementation of the principles of transparency and accountability in the management of village funds by the Cepogo Village Government to achieve good governance standards. This study uses a descriptive qualitative approach. The data collection technique used was direct interviews with a semi-structured method. The participants of this study were the Village Head of Administration, Village Secretary, Village Treasurer, and staff of the Administration Section for managing the village fund who are responsible for managing it. The results showed that the planning and implementation of Village Fund Program activities had shown accountable and transparent management. In terms of accountability, both physical and management activities, it has shown that the implementation is accountable and transparent.
\end{abstract}

Keywords: Accountability; Cepogo village; Good governance; Government governance; Transparency; Village fund program.

\begin{abstract}
Abstrak. Program dana desa merupakan wujud kepedulian pemerintah terhadap pembangunan wilayah perdesaan. Pengelolaan dana desa pada setiap tahapannya, yaitu perencanaan, pelaksanaan, penatausahaan, pelaporan, dan pertanggungjawaban seharusnya didasarkan pada prinsip-prinsip good governance. Pemerintah Desa Cepogo, Kecamatan Cepogo, Kabupaten Boyolali, Provinsi Jawa Tengah adalah salah satu pemerintah desa di Indonesia yang telah melaksanakan prinsip good governance dalam pengelolaan dana desa. Penelitian ini bertujuan untuk mengetahui bagaimana implementasi prinsip transparansi dan akuntabilitas terhadap pengelolaan dana desa oleh Pemerintah Desa Cepogo untuk mencapai standar good governance. Penelitian ini
\end{abstract}


menggunakan pendekatan diskriptif-kualitatif. Teknik pengumpulan data yang digunakan adalah wawancara langsung dengan metode semi terstruktur. Partisipan dalam penelitian ini terdiri atas Kepala Desa, Sekretaris Desa, Bendahara Desa, dan Staf Administrasi pengelolaan dana desa yang bertanggungjawab terhadap pengelolaan dana desa tersebut. Hasil penelitian ini menunjukkan bahwa perencanaan dan pelaksanaan kegiatan program dana desa memperlihatkan pengelolaan yang akuntabel dan transparan. Dari sisi akuntabilitas, baik dari segi fisik maupun penatalaksanaan program telah menunjukkan pelaksanaan yang akuntabel dan transparan.

Kata kunci: Akuntabilitas; Desa Cepogo; Good governance; Program dana desa; Tata kelola pemerintahan; Transparansi.

Article Info:

Received: January 16, $2020 \quad$ Accepted: September 14, 2020 Available online: February 16, 2021

DOI: http://dx.doi.org/10.30588/jmp.v10i2.628

\section{LATAR BELAKANG}

Undang-Undang Republik Indonesia nomor 6 tahun 2014 tentang desa menyatakan bahwa desa merupakan kesatuan masyarakat hukum yang memilikibatas wilayah kewenangan untuk mengatururusan pemerintahan, kepentingan masyarakat setempat berdasarkan prakarsa masyarakat, hak asal usul, dan/atau hak tradisional yang diakui dan dihormati dalam sistem pemerintahan Negara Kesatuan Republik Indonesia. Undang-Undang Desa bersentuhan langsung dengan kehidupan masyarakat melalui kegiatan layanan publik. Berdasarkan Undang-Undang Desa tersebut, sebuah desa diberikan penguatan kewenangan dalam menyelenggarakan pemerintahan, melaksanakan pembangunan, melakukan pembinaan kemasyarakatan, dan memberdayakan masyarakat desa tersebut. Selain itu, desa juga diberikan kewenangan terhadap sumbersumber pendapatannya.

Desa diberikan kewenangan dan sumber dana yang memadai agar dapat mengelola potensiyang dimilikinya guna meningkatkan ekonomi dan kesejahtaraan masyarakatnya. Setiap tahun, pemerintah pusat telah menganggarkan dana desa yang cukup besar untuk diberikan dan dikelola desa sendiri. Data Kementerian Keuangan memperlihatkan bahwa dana desa telah dianggarkan tahun 2015 sebesar Rp20,7 triliun, sehingga setiap desa rata-rata mendapatkan alokasi sekitar Rp280 juta. Selanjutnya, anggaran dana desa pada tahun 2016 meningkat menjadi Rp46,98 triliun dengan rata-rata setiap desa mendapatkan alokasi sekitar Rp628 juta, sedangkan dana desa pada tahun 2017 kembali meningkat menjadi Rp60 triliun dengan rata-rata setiap desa mendapatkan alokasi sekitar Rp800 juta (Kemenkeu, 2017).

Badan Akuntabilitas Keuangan Negara (BAKN) DPR RI menemukan adanya beberapa permasalahan utama pengelolaan dana desa, baik pada aspek pembinaan maupun pengawasannya (Sartono, 2019). Permasalahan pada aspek pembinaan pengelolaan dana desa, antara lain belum adanya regulasi penetapan standar akuntansi pemerintahan desa dan regulasi penyelenggaraan dan pembinaan aparatur desa yang lengkap. Di sisi lain, permasalahan pada aspek pengawasan pengelolaan dana desa, antara lain perencanaan dan pengawasan oleh pemerintah daerah yang belum mempertimbangkan faktor 
risiko. Hal tersebut terlihat dari adanya pemerintah daerah yang tidak memiliki rencana dan pemetaan masalah dalam pembuatan kegiatan pengawasan (DPR RI, 2019).

Permasalahan-permasalahan yang muncul dalam pengelolaan dana desa tersebut mengakibatkan beberapa kepala desa menghadapi masalah dengan aturan hukum.Hal itu dapat terjadi karena sebagian kepala desa belum sepenuhnya memahami tata kelola dan tata regulasi dana desa. Misalnya, Kejaksaan Negeri Boyolali mengungkapkan adanya kasus dugaan penyimpangan pengelolaan dana desa oleh oknum kepala desa meliputi lelang tanah kas desa dan uang hasil lelangnya tidak dimasukkan dalam Anggaran Pendapatan dan Belanja Desa (detik.com, 2019).

Pemahaman dan pemenuhan ketentuan dalam peraturan pengelolaan dana desa bagi para stakeholders, khususnya perangkat desa menjadi faktor penting keberhasilan dan keberlanjutan pembangunan desa sesuai amanat Undang-Undang Desa. Tujuan penelitian ini adalah untuk mengetahuibagaimana penerapan prinsip transparansi dan akuntabilitas dalam pengelolaan dana desauntuk mencapai standar good governance di Desa Cepogo, Kecamatan Cepogo, Kabupaten Boyolali, Provinsi Jawa Tengah.

\section{KAJIAN TEORITIS}

\section{Agency Theory}

Teori agensi adalah kontrak antara manajer (agents) dengan pemilik (principals). Hubungan kontraktual ini dapat berjalan dengan baik, apabila pemilik mendelegasikan otoritas pembuatan keputusan kepada manajer. Hubungan keagenan ditunjukkan oleh pihak principals yang memberikan mandat kepada pihak lain, yaitu agents untuk melakukan semua kegiatan atas namanya dalam kapasitas sebagai pengambil keputusan (Jensen \&Meckling, 1976). Pada sistem pemerintahan daerah di Indonesia, secara sadar maupun tidak, teori agensi sebenarnya telah dipraktikkan. Pada organisasi sektor publik, principals yang dimaksud adalah rakyat, sedangkan agen adalah pemerintah. Dalam konteks penelitian ini, agen adalah kepala desa dan aparat desa lainnya (Ismail, Widagdo, \& Widodo, 2016).

Teori agensi memandang bahwa pemerintah desa, yaitu kepala desa dan aparat desa lainnya sebagai agents bagi masyarakat desa (principals) yang akan bertindak dengan penuh kesadaran bagi kepentingan desa mereka sendiri. Hubungan kontrak yang dimaksud adalah pendelegasian wewenang kepada agents untuk melakukan semua pekerjaannya secara bertanggungjawab kepada pemerintah daerah (kabupaten dan provinsi) maupun pusat yang telah menetapkan ketentuan berupa Peraturan Menteri Dalam Negeri (Permendagri) nomor 113 tahun 2014 tentang Pengelolaan Keuangan Desa. Aparatur desa menjadi kepanjangan tangan masyarakat desa sebagai pemberi amanah dalam pelaksanaan tugas-tugasnya sesuai Permendagri tersebut (Pemerintah Desa Panggungharjo, 2014).

\section{Dana Desa}

Pengertian dana desa menurut Buku Saku Dana Desa adalah dana APBN (Anggaran Pendapatan dan Belanja Negara) yang diperuntukkan bagi desa yang ditransfer melalui APBD (Anggaran Pendapatan dan Belanja Daerah) kabupaten/kota dan diprioritaskan untuk pelaksanaan pembangunan dan pemberdayaan masyarakat desa (Kemenkeu, 2017). Dana desa sebagai salah satu sumber pendapatan desa, pengelolaannya 
dilakukan dalam rerangka pengelolaan keuangan desa. Keuangan desa dikelola berdasarkan asas-asas transparan, akuntabel, partisipatif, dan dilaksanakan secara tertib dan disiplin anggaran (Pemerintah Desa Panggungharjo, 2014). Pengelolaan keuangan desa meliputi aktifitas perencanaan, pelaksanaan, penatausahaan, pelaporan, dan pertanggungjawaban (Kemenkeu, 2017). Masing-masing aktifitas dalam pentahapan pengelolaan keuangan desa diuraikan berikut ini.

1. Tahap Perencanaan meliputi aktifitas:

a. Sekretaris Desa (Sekdes) menyusun Raperdes (Rancangan Peraturan Desa) tentang APBDes (Anggaran Pendapatan dan Belanja Desa) yang akan dibahas dan disepakati antara Kades (Kepala Desa) dan BPD (Badan Permusyawaratan Desa)

b. APBDes disampaikan kepada Bupati/Walikota melalui Camat paling lambat bulan Oktober tahun berjalan.

c. APBDes dievaluasi oleh Bupati/Walikota selama maksimal 20 hari kerja, dan Kepala Desa harus melakukan penyempurnaan selama 7 hari, jika APBDes dinyatakan tidak sesuai dengan Raperdes.

d. Prioritas penggunaan dana desa ditetapkan dalam musyawarah desa antara BPD, Pemdes (Pemerintah Desa), dan unsur masyarakat.

2. Tahap Pelaksanaan meliputi aktifitas:

a. Pengeluaran dan penerimaan dana dilaksanakan melalui rekening Kas Desa atau sesuai ketetapan pemerintah kabupaten/kota dengan dukungan bukti yang lengkap dan sah.

b. Pemdes dilarang melakukan pungutan selain yang telah ditetapkan dalam Perdes.

c. Bendahara Desa dapat menyimpan uang dalam Kas Desa yang besarannya ditetapkan dengan Perbup/Perwali (Peraturan Bupati/Peraturan Walikota).

d. Pengadaan barang dan/atau jasa di desa diatur dengan Perbup/Perwali.

e. Penggunaan biaya tak terduga harus dibuat rincian RAB (Rencana Anggaran Belanja) dan disahkan oleh Kades.

3. Tahap Penatausahaan meliputi aktifitas:

a. Tahapan ini wajib dilaksanakan oleh Bendahara Desa.

b. Pencatatan setiap penerimaan dan pengeluaran kas.

c. Melakukan tutup buku setiap akhir bulan.

d. Mempertanggungjawabkan pengelolaan dana melalui laporan.

e. Laporan pengelolaan dana disampaikan setiap bulan kepada Kades paling lambat tanggal 10 bulan berikutnya.

f. Menggunakan Buku Kas Umum, Buku Kas Pembantu Pajak, dan Buku Bank.

4. Tahap Pelaporan dan Pertanggungjawaban meliputi aktifitas:

a. Kades menyampaikan laporan kepada Bupati/Walikota melalui Camat yang terdiri atas laporan realisasi pelaksanaan APBDes semester pertama dan semester akhir tahun.

b. Laporan pertanggungjawaban realisasi Pelaksanaan APBDes disampaikan setiap akhir tahun anggaran yang terdiri ataspendapatan, belanja, dan pembiayaanyang ditetapkan dengan Perdes.

c. Lampiran format laporan terdiri atas:

1) Pertanggungjawaban realisasi pelaksanaan APBDes tahun anggaran berjalan.

2) Kekayaan milik desa per 31 Desember tahun anggaran berjalan.

3) Program pemerintah danpemerintah daerah yangg masuk ke desa. 


\section{Good Governance}

Governance merupakan paradigma baru dalam tatanan pengelolaan kepemerintahan. Pergeseran paradigma tata pemerintahan menekankan pada kolaborasi dalam kesetaraan dan keseimbangan tiga pilar governance, yaitu transparansi, akuntabiltas, dan partisipatif dengan mengembangkan paradigma baru administrasi publik sebagai tata pemerintahan yang baik atau good governance (Astuti \& Yulianto, 2016). Dalam rangka mendukung terwujudnya tata kelola yang baik (good governance) dalam penyelenggaraan pemerintahan desa, pengelolaan keuangan desa dilakukan berdasarkan prinsip tata kelola yang transparan, akuntabel, dan partisipatif, serta dilakukan dengan tertib dan disiplin anggaran. Karakteristik good governance terdiri atas partisipasi, supremasi hukum, transparansi, cepat tanggap, membangun konsensus, kesetaraan, efektif dan efisien, bertanggungjawab, serta memiliki visi strategik (LAN \& BPKP, 2000).

Good governance menjadi kebutuhan mutlak bagi masyarakat demi terciptanya sebuah sistem pemerintahan yang lebih berpihak kepada kepentingan rakyat sesuai prinsip-prinsip demokrasi secara universal (Tomuka, 2015). United Nations Development Program atau UNDP (1997) memberikan panduan karakteristik atau prinsip pelaksanaan good governance yang meliputi:

a. Participation yaitu keterlibatan masyarakat dalam pembuatan keputusan, baik secara langsung maupun tidak langsung melalui lembaga perwakilan yang dapat menyalurkan aspirasi mereka.

b. Rule of law yakni rerangka hukum yang adil dan dilaksanakan tanpa pandang bulu.

c. Transparency yang diartikan adanya keterbukaan terhadap publik, sehingga pihak yang berkepentingan dapat mengetahui kebijakan dan kinerja pemerintah.

d. Responsiveness yaitu birokrat yang cepat tanggap dan harus segera menyadari apa yang menjadi kepentingan publik (public interest), sehingga mereka cepat melakukan pembenahan. Dalam hal ini, aparatur birokrasi yang memberikan layanan publik harus cepat beradaptasi dalam suatu model pelayanan yang prima.

e. Consensus orientation adalah orientasi pada kepentingan masyarakat yang lebih luas.

f. Equity yang diartikan bahwa masyarakat, baik laki-laki maupun perempuan, miskin maupun kaya, memiliki kesamaan dalam memperoleh layanan publik oleh aparatur birokrasi. Dalam hal ini, aparatur birokrasi tidak boleh melakukan diskriminatif dalam memberikan layanan kepada pihak-pihak yang perlu dilayani.

g. Efficienty and Effectiveness yaitu tercapainya sasaran dan upaya mencapainya dengan usaha yang tidak berlebihan atau hemat. Layanan publik adalah tindakan melayani masyarakat seefektif mungkin dan tanpa banyak prosedur yang berbelit.

h. Accountability adalah pertanggungjawaban kepada publik atas setiap aktifitas yang dilakukan. Akuntabilitas berarti kewajiban untuk memberi pertanggungjawaban dan berani bertanggung jawab atas kinerja atau tindakan yang dilakukan.

i. Strategic vision adalah visi ke depan yang dimiliki penyelenggara pemerintahan, Pemerintah dan masyarakat seharusnya memiliki kesatuan pandangan sesuai visi yang mereka agar tercipta keselarasan dan integrasi pembangunan dengan memperhatikan latar belakang sejarah, kondisi sosial, dan budaya masyarakat.

Dari karakteristik atau prinsip-prinsip tersebut, setidaknya ada tiga hal yang dapat diperankan oleh good government governance, yaitu penciptaan transparansi, akuntabilitas publik, dan value for money (economy, efficiency, dan effectiveness) (Rahadian, 
2010). Mewujudkan good government governance dapat diartikan sebagai terciptanya sebuah layanan publik atau tata kelola pemerintahan yang bersih dan akuntabel. Penelitian yang dilakukan ini memfokuskan perhatian pada pelaksanaan dua prinsip good governance, yaitu transparansi dan akuntabilitas.

\section{Transparansi}

Transparansi atau keterbukaan memberikan arti bahwa anggota masyarakat memiliki hak dan akses yang sama untuk mengetahui proses anggaran karena menyangkut aspirasi dan kepentingan masyarakat, terutama pemenuhan kebutuhan-kebutuhan hidup masyarakat banyak. Transparansi merupakan prinsip yang harus ada dan meliputi keseluruhan bagian pengelolaan keuangan baik dari proses perencanaan, pelaksanaannya (Rahum, 2015) Prinsip transparansi diwujudkan dalam perencanaan ADD (Alokasi Dana Desa)yang melibatkan perangkat desa, BPD sebagai wakil masyarakat desa, LPMD (Lembaga Pemberdayaan Masyarakat Desa) sebagai mitra pemerintah desa dalam pengerjaan kegiatan fisik, dan tokoh masyarakat dalam pengambilan keputusan untuk mengeloladana desa (Putra, Sinarwati, \& Wahyuni, 2017).

Permendagri nomor 37 tahun 2007 tentang Pedoman Pengelolaan Keuangan Daerah pada pasal 4 ayat 7 menyebutkan bahwa transparansi adalah prinsip keterbukaan yang memungkinkan masyarakat untuk mengetahui dan mendapatkan akses informasi seluas-luasnya tentang keuangan daerah (Kemendagri, 2007). Di sisi lain, Krina (2003) menyatakan bahwa transparansi adalah prinsip yang menjamin akses atau kebebasan bagi setiap orang untuk memperoleh informasi tentang penyelenggaraan pemerintahan, yakni informasi tentang kebijakan, proses pembuatan, dan pelaksanaannya, serta hasilhasil yang dicapai.

Coryanata (2012) mengatakan transparansi dibangun atas dasar arus informasi yang bebas, proses pemerintahan yang baik, kinerja lembaga-lembaga dan informasi dapat diakses oleh pihak-pihak yang berkepentingan, dan informasi yang tersedia harus memadai agar dapat dipahami dan dipantau secara rutin. Anggaran yang disusun oleh pihak eksekutif dikatakan transparan, apabila laporan tersebut memenuhi beberapa kriteria sebagai berikut (Coryanata, 2012): (1) terdapat pengumuman kebijakan anggaran; (2) tersedia dokumen anggaran dan mudah diakses; (3) tersedia laporan pertanggungjawaban yang tepat waktu; (4) terakomodasinya suara/usulan rakyat; dan (5) terdapat sistem pemberian informasi kepada publik.

\section{Akuntabilitas}

Akuntabilitas (accountability) adalah kewajiban untuk memberikan pertanggungjawaban, menjawab, dan menjelaskan kinerja dan tindakan seseorang atau badan hukum atau pimpinan suatu organisasi kepada pihak yang memiliki hak atau kewenangan untuk meminta keterangan atau pertanggungjawaban tersebut (Astuti \& Yulianto, 2016). Dalam penelitian ini, akuntabilitas diartikan sebagai pertanggungjawaban publik (Farida, Jati, \& Harventy, 2018). Artinya, semua kegiatan yang menyangkut urusan publik harus dapat dipertanggungjawabkan kepada publik mulai dari perencanaan, pelaksanaan hingga pelaporannya.

Masyarakat tidak hanya berhak untuk mengetahui tentang pengelolaan keuangan pemerintah. Lebih dari itu, masyarakat juga dapat menuntut tanggung jawab pemerintah terkait pengelolaan keuangan tersebut (Farida et al., 2018). Menurut Arifiyanto dan Kurrohman (2014), akuntabilitas merupakan sistem pengelolaan dana desa sebagai 
upaya untuk mewujudkan tata kelola pemerintahan yang baik (good government governance). Prinsip pelaksanaan good governance melibatkan partisipasi, transparansi, dan pertanggungjawaban dalam pelaksanaan pemerintahan maupun pembangunan (Arifiyanto \& Kurrohman, 2014).

\section{METODE PENELITIAN}

Jenis penelitian yang digunakan dalam penelitian ini adalah diskriptif-kualitatif. Penelitian kualitatif adalah penelitian yang bermaksud untuk memahami fenomena tentang apa yang dialami oleh subyek penelitian, misalnya perilaku, persepsi, motivasi, tindakan, dan lain-lain, secara holistik dan mendiskripsikannya dalam bentuk kata-kata dan bahasa pada suatu konteks khusus yang alamiah dengan memanfaatkan berbagai metode alamiah (Moleong, 2013, 5).

Dalam penelitian ini, teknik pengumpulan data yang digunakan adalah wawancara langsung kepada pihak-pihak yang dianggap berkepentingan dengan pengelolaan dana desa sebagai informan. Wawancara langsung dilakukan dengan metode semi terstruktur dengan cara berdialog langsung dengan informan berdasarkan pertanyaan protokol yang telah disiapkan. Informan terdiri atas mereka yang dipilih, karena mereka diyakini memiliki pengetahuan yang cukup tentang pengelolaan dana desa. Penelitian ini menetapkan empat orang informan, yaitu Kepala Desa, Sekretaris Desa, Kepala Urusan (Kaur) Keuangan atau Bendahara Desa, dan Staf Administrasi. Metode semi terstruktur ini digunakan untuk mengungkap permasalahan penelitian secara lebih terbuka melalui penjelasan, pendapat, dan ide-ide para informan terpilih. Dalam proses wawancara, penelitian ini berusaha untuk mendapatkan data secara rinci dan mencatat semua hal (transkripsi) yang dikemukakan informan (Moleong, 2013, 191).

Analisis data dapat diartikan sebagai cara melaksanakan analisis terhadap data dengan tujuan untuk mengolah data menjadi sebuah informasi, sehingga data tersebut dapat bermanfaat dalam menjawab masalah-masalah yang berkaitan dengan kegiatan penelitian. Analisis data bertujuan untuk mengungkapkan data apa yang perlu dicari, dugaan apa yang perlu diuji, pertanyaan apa yang perlu dijawab, metode apa yang harus digunakan untuk mendapatkan informasi baru, serta kesalahan apa yang perlu diperbaiki. Selain itu, analisis data juga bertujuan untuk mendiskripsikan data, sehingga karakteristik data dapat dipahami. Selanjutnya, kesimpulan dibuat atas dasar dugaan atau estimasi.

Analisis data yang digunakan dalam penelitian ini dilakukan dengan langkahlangkah sesuai pendapat Moleong $(2013,248)$ sebagai berikut: (1) Pemrosesan satuan obyek penelitian dengan membaca dan mempelajari secara teliti seluruh data yang terkumpul. Setelah itu satuan-satuan diidentifikasi dan dimasukkan ke dalam indeks; (2) Kategorisasi yang diartikan sebagai proses penyusunan kategori data. Transkripsi hasil wawancara ditentukan kategorinya, yaitu mengelompokkan kartu-kartu pengumpulan data yang telah dilakukan ke dalam bagian-bagian isi yang saling berkaitan; (3) Penafsiran data yaitu hasil diskripsi dari pengumpulan data dilakukan pembahasan dengan menghubungkannya dengan teori yang berkaitan dalam penelitian ini, yakni transparansi dan akuntabilitas pengelolaan dana desa. 


\section{HASIL DAN PEMBAHASAN}

\section{Gambaran Obyek Penelitian}

Desa Cepogo tidak banyak memiliki catatan sejarah secara tertulis. Namun, keberadaan Desa Cepogo tidak terlepas dari keberadaan Pedukuhan Tumang yang dijadikan sebagai pusat pemerintahan desa, sehingga sejarah Tumang lebih menonjol daripada Cepogo. Hal tersebut terkait dengan keberadaan Pedukuhan Tumang sebagai wilayah industri kerajinan logam yang lebih banyak dikenal masyarakat luas, baik di dalam negeri maupun luar negeri daripada nama Cepogo yang menjadi nama desa.

Pada tahun 2018, penduduk Desa Cepogo berjumlah 8.104 jiwa dengan komposisi jumlah penduduk laki-laki sebanyak 4.060 atau 50,09\% dan jumlah penduduk perempuan sebanyak 4.044 atau 49,91\% dengan tingkat kepadatan penduduk sebesar 2.103 jiwa/km persegi dan jumlah Kepala Keluarga (KK) sebanyak 2.649 KK. Penelitian kualitatif ini melibatkan empat orang informan yang diwawancara untuk mendapatkan data primer yang dianalisis. Keempat orang informan aparat Desa Cepogo tersebut meliputi Kepala Desa, Sekretaris Desa, Bendahara Desa, dan Staf Administrasi. Keempatnya terlibat langsung dalam penyusunan program dalam pengelolaan dana desa dan laporan pelaksanaannya. Identifikasi umum terhadap keempat informan penelitian ini disajikan pada Tabel 1 .

Tabel 1. Identifikasi Informan

\begin{tabular}{ccccccc}
\hline Informan & $\begin{array}{c}\text { Nama } \\
\text { (inisial) }\end{array}$ & Gender & Jabatan & $\begin{array}{c}\text { Usia } \\
\text { (tahun) }\end{array}$ & Pendidikan & $\begin{array}{c}\text { Masa Kerja } \\
\text { (tahun) }\end{array}$ \\
\hline 1 & $\mathrm{Ma}$ & $\mathrm{L}$ & Kepala Desa & 52 & SMA & 8 \\
\hline 2 & $\mathrm{Ri}$ & $\mathrm{P}$ & Sekretaris Desa & 45 & Diploma & 6 \\
\hline 3 & $\mathrm{Nu}$ & $\mathrm{P}$ & Bendahara Desa & 37 & Sarjana & 6 \\
\hline 4 & $\mathrm{Ra}$ & $\mathrm{L}$ & Staf Administrasi & 34 & Sarjana & 4 \\
\hline
\end{tabular}

Keterangan: L=Laki-laki; P=Perempuan; SMA (Sekolah Menengah Atas).

Sumber: Hasil pengumpulan data primer yang diolah (2019).

\section{Pengelolaan Dana Desa}

Pengelolaan dana desa di Desa Cepogo didasarkan pada Permendagri nomor 113 tahun 2014 tentang pengelolaan keuangan desa yang terdiri atas prosedur perencanaan, pelaksanaan, dan pertanggungjawaban dana desa oleh Pemerintah Desa Cepogo. Penelitian ini menganalisis sumber pendapatan desa yang berasal dari alokasi APBN berupa dana desa. Pengelolaan dana desa menjadi obyek utama penelitian ini, karena pemerintah desa mendapatkan kewenangan langsung dari pemerintah pusat melalui Undang-Undang nomor 6 tahun 2014 tentang desa.

Tabel 1. Rincian Dana Desa yang Diterima Desa Cepogo

\begin{tabular}{cc}
\hline Tahun & Realisasi Dana Desa (Rp) \\
\hline 2017 & 849.281 .000 \\
2018 & 911.926 .000 \\
2019 & 1.106 .186 .000
\end{tabular}

Sumber: Laporan Realisasi Dana Desa Cepogo Tahun 2017-2019. 
Setiap tahun, pemerintah pusat telah menganggarkan dana desa yang sangat besar untuk diberikan kepada desa-desa di seluruh Indonesia. Desa Cepogo mendapatkan kewenangan dan sumber dana yang cukup besar untuk dikelola sendiri dalam rangka meningkatkan ekonomi dan kesejahteraan masyarakatnya. Tabel 2 menunjukkan rincian dana desa yang telah diterima dan digunakan bagi pembangunan Desa Cepogo untuk periode tahun 2017-2019.

Tabel 2 menunjukkan bahwa sejak tahun 2017 hingga 2019, Desa Cepogo telah menerima alokasi dana desa dari pemerintah pusat dengan jumlah yang semakin besar. Besaran dana desa yang diterima Desa Cepogo pada setiap tahunnya tidak sama, tetapi cenderung meningkat. Pengalokasian APBDes untuk dana desa tergantung dari kemampuan APBN. Perhitungan pengalokasian dana desa berpatokan pada Peraturan Pemerintah (PP) nomor 60 tahun 2014 tentang Dana Desa yang bersumber dari Anggaran Pendapatan dan Belanja Daerah yang kemudian diganti dengan PP nomor 22 tahun 2015 tentang Perubahan atas Peraturan Pemerintah Nomor 60 tahun 2014 tentang Dana Desa yang bersumber dari Anggaran Pendapatan dan Belanja Daerah (Kemenkeu, 2014).

Pengelolaan dana desa di Desa Cepogo memiliki mekanisme yang dimulai dari pembentukan Tim Penyusun Rencana Kerja Pemerintah Desa (RKPDes) yang dibuat oleh Pemerintah Desa Cepogo. Tim ini melibatkan aparatur desa dan masyarakat secara umum, yakni kepala desa sebagai pembina, sekretaris desa, kepala urusan perencanaan, lembaga-lembaga yang ada di desa, dan BPD. Keberadaan tim ini bertujuan agar pembangunan desa dapat lebih terarah untuk meningkatkan kualitas hidup masyarakat Desa Cepogo. Hasil wawancara terhadap beberapa informan menjelaskan mengenai mekanisme sebelum pengelolaan dana desa, seperti yang diuraikan oleh Informan 1 dan Informan 2 berikut ini:

"Jadi kita pertama-tama bikin tim dulu sebelum adanya musyawarah ituyang isinya perwakilan pemerintah desa, ada juga dari perwakilan masing-masing lembaga." (Informan 2, Sekretaris Desa).

"Rencana Pembangunan Jangka Menengah Desa itu dilaksanakan... kemudian dirapatkan dengan BPD dan masyarakat.... nanti arahnya setelah itu dilaksanakan croscek selesai masuk ke RKP Desa itu akan dimusrenbangkan" (Informan 1, Kepala Desa).

"[...] masyarakat diajak bicara, namun sebelum diajak bicara, sebelumnya kita desa sudah mengetahui potensi dan masalah yang ada. Jadi, pada akhirnya yang kita harapkan itu adalah masukan dari masyarakat itu sesuai dengan kebutuhan masayarakat, namun tidak terlepas dari apa yang menjadi hasil dari pengecekan lapangan atau croscek di pemerintah desa [...]" (Informan 1, Kepala Desa).

Mekanisme pembentukan Tim Penyusun RKPDes yang dibuat oleh Pemerintah Desa Cepogo telah sesuai dengan Permendagri No 114 tahun 2014 tentang pedoman pembangunan desa yang terdapat pada pasal 33 mengenai pembentukan Tim Penyusun RKPDes dan sesuai dengan Peraturan Daerah Kabupaten Boyolali nomor 03 tahun 2012 tentang sistem perencanaan pembangunan partisipatif daerah pada pasal 1 yang berisi mengenai Sistem Perencanaan Pembangunan Partisipatif Daerah atau SP3D, yaitu usaha sistematis untuk merumuskan strategi perencanaan pembangunan daerah dengan melibatkan masyarakat melalui pelaksanaan forum Satuan Kerja Perangkat Daerah (SKPD). 


\section{Perencanaan}

Dana Desa adalah dana APBN yang diperuntukkan bagi Desa yang ditransfer melalui APBD kabupaten/kota dan diprioritaskan untuk pelaksanaan pembangunan dan pemberdayaan masyarakat desa (Kemenkeu, 2017). Oleh karena itu, program perencanaan dan kegiatannya disusun melalui forum Musyawarah Perencanaan Pembangunan Desa (Musrenbangdes). Musrenbangdes adalah forum musyawarah yang membahas usulan-usulan rencana kegiatan pembangunan desa yang berpedoman pada prinsipprinsip Perencanaan Pembangunan Partisipasi Masyarakat Desa (P3MD). Prinsip partisipasi adalah keterlibatan warga negara di dalam pengambilan keputusan baik secara langsung maupun melalui institusi yang mewakili kepentingannya (Tjokroamidjojo, 2000). Pelaksanaan prinsip partisipasi tersebut juga telah dibuktikan dengan hasil wawancara sebagai berikut:

"Perencanaan ADD sudah dilaksanakan sesuai dengan prinsip partisipasi. Sebelum dilaksanakan kegiatan terlebih dahulu dilakukan musyawarah desa guna membahas perencanaan pembangunan dan yang melaksanakan pembangunan adalah warga setempat di mana kegiatan pembangunan tersebut dilaksanakan [...] “ (Informan 1, Kepala Desa).

Dalam perencanaan kegiatan-kegiatan yang dananya bersumber dari dana desa harus benar-benar memperhatikan kebutuhan masyarakat, karena dana desa merupakan sumber pendapatan utama desa-desa di Kabupaten Boyolali termasuk Desa Cepogo. Oleh karena itu, rencana penggunaan dana desa juga menjadi bahan utama penyusunan APBDes yang dimusyawarahkan di tingkat desa dan disepakati oleh pemerintah desa dan BPD sebagai perwakilan masyarakat desa sebagai pedoman kegiatan pembangunan, kemasyarakatan, dan pelayanan kepada masyarakat desa selama satu tahun sebagaimana disampaikan oleh Informan 1 sebagai berikut:

"[...] untuk prinsip di pemerintahan desa Cepogo.... ini kita melaksanakan croscek, artinya memang betul-betul di cek ke bawah.... sehingga pembuatan Rencana Pembangunan Jangka Menengah Desa itu dilaksanakan secara croscek untuk mengetahui potensi dan masalah yang ada .... setelah dirangkum, kemudian dirapatkan dengan BPD dan masyarakat... nanti arahnya setelah itu dilaksanakan croscek selesai masuk ke RKP Desa itu akan dimusrenbangkan... sehingga pola Musrenbang inilah yang nantinya menentukan mana yang harus dibangun [...]" (Informan 1, Kepala Desa).

"Misalnya, potensi disini bisa dikembangkan apa itu masyarakat semua diajak ngomong. Nanti akan kita florkan pada saat Musrenbang Desa......... setelah RPJM Desa, baru RKP yang digunakan selama enam tahun itu. Jadi, keinginan masyarakat dalam pelaksanaan disiplin pembangunan itu bukan hasil dari keinginan mereka, tapi akan disandingkan antara hasil dari croscek potensi dan masalah yang ada dengan masyarakat menginginkan semacam apa" (Informan 1, Kepala Desa).

Pendapat Informan 1 tersebut mencerminkan adanya komitmen bersama antara pemerintah daerah dengan masyarakat untuk melakukan proses pembelajaran di dalam meningkatkan partisipasi masyarakat dengan tetap menitikberatkan pada pemberdayaan masyarakat. Namun dalam pelaksanaannya harus disesuaikan dengan kondisi masingmasing desa untuk menumbuhkan potensi desa tersebut. Pada prinsipnya penggunaan 
dana desa terbagi menjadi dua, yaitu dana operasional pemerintah desa dan dana untuk pemberdayaan masyarakat desa.

Hasil perencanaan tersebut akan menjadi pedoman penyelenggaraan pemerintahan desa dan pembangunan desa dalam kurun waktu satu tahun. Dengan demikian perencanaan yang telah disepakati juga harus transparan dan dapat diketahui oleh seluruh lapisan masyarakat yang nantinya dapat dipertanggungjawabkan. Dari sisi transparansi perencanaan, seluruh pemerintah desa di Kecamatan Cepogo diwajibkan untuk memberikan informasi kepada masyarakat tentang kegiatan apa yang akan dilakukan yang dananya bersumber dari dana desa. Hal tersebut menunjukkan bahwa perencanaan dana desa di Desa Cepogo juga telah melaksanakan prinsip transparansi dan akuntabilitas.

Prinsip transparansi dijunjung tinggi oleh pelaksana program dana desa di Desa Cepogo sehingga diharapkan memperoleh imbal balik/tanggapan masyarakat di dalam memperbaiki kinerja pembangunan. Di samping itu pemberian informasi dilaksanakan secara terbuka mulai dari tahap perencanaan sampai paska kegiatan pembangunan. Hal tersebut dibuktikan dari hasil wawancara dengan informan salah seorang Tim Pelaksana Desa sebagai berikut:

"Pengelola Dana Desa memberikan informasi kepada masyarakat melalui papan informasi terkait dengan papan informasi ada papan proyek yang dipasang di titik proyek tersebut dilaksanakan, dan yang kedua melalui pertanggungjawaban kepada Badan Permusyawaratan Desa (BPD) selaku wakil dari masyarakat desa" (Informan 1, Kepala Desa).

Informasi tersebut menunjukkan adanya penerapan prinsip transparansi di dalam perencanaan dana desa yang dapat diketahui oleh seluruh masyarakat desa. Jika tahap perencanaan dana desa selesai, maka tahap selanjutnya adalah tahap pelaksanaan kegiatan-kegiatan yang bersumber dari dana desa.

\section{Pelaksanaan}

Berdasarkan Peraturan Daerah Kabupaten Boyolali nomor 7 tahun 2016 mengenai Pengelolaan Keuangan Daerah, Kepala Desa dibantu oleh Pejabat Pelaksana Teknis Kegiatan (PPTK) dalam melaksanakan pengelolaan keuangan desa. Dalam hal pelaksanaan program dana desa di Desa Cepogo juga menjunjung tinggi prinsip partisipatif dalam pengambilan keputusan dan transparansi, seperti yang disampaikan oleh informan sebagai berikut:

"Pelaksana ADD sudah melaksanakan prinsip transparansi karena dari proses perencanaan, pelaksanaan sampai dengan pertanggungjawaban selalu melibatkan unsur-unsur masyarakat termasuk Badan Permusyawaratan Desa, Lembaga Permusyawaratan Masyarakat Desa, dan tokoh masyarakat" (Informan 1, Kepala Desa).

Hasil wawancara tersebut sesuai dengan konsep transparansi (Tjokroamidjojo, 2000), yaitu dapat diketahui oleh banyak pihak (yang berkepentingan) mengenai perumusan kebijakan (politik) dari pemerintah, organisasi, badan usaha. Dari sisi prinsip akuntabilitas pelaksanaan ADD ditempuh melalui sistem pelaporan yaitu laporan bulanan dan laporan masing-masing tahapan kegiatan. Berikut hasil wawancara sebagai berikut: 
"Sistem pelaporan kegiatan ADD dilaksanakan secara bertahap sesuai dengan pencairan ADD. Tahapan pencairan ADD ada tiga tahap yang pertama 40\%, kedua 40\%, ketiga 20\%. Jadi pertama 20 kemudian setelah kita bisa menyajikan SPJnya, yaitu ditransfer tahap kedua, nah pada tahap kedua bisa menyajikan SPJnya baru ditransfer ke tahap ketiganya. Jadi, otomatis masuknya meski hanya satu rekening tapi secara otomatis ini asalnya dari dari dana desa atau Alokasi Dana Desa itu pasti akan kelihatan" (Informan 3, Bendahara Desa).

Hasil wawancara tersebut menunjukkan bahwa di dalam pelaksanaan dana desa senantiasa dilaporkan perkembangan pelaksanaan kegiatan oleh pengelola dana desa di tingkat desa, terutama tentang kegiatan fisik dan penyerapan dana, dengan demikian dapat diketahui bahwa tanggungjawab pengelola dana desa di tingkat desa sudah memenuhi ketentuan pembuatan laporan kegiatan dana desa yang bertahap dan laporan akhir kegiatan.

Pertanggungjawaban pelaksanaan program dana desa kepada pemerintah tingkat atasnya dilakukan melalui sistem pelaporan yang secara bertahap. Laporan pelaksanaan dana desa terdiri dari laporan pendahuluan, laporan masing-masing tahap kegiatan, laporan bulanan dan laporan akhir kegiatan yang disusun secara komprehensif.

\section{Pertanggungjawaban}

Akuntabilitas adalah tanggung gugat dari pengurusan atau penyelenggaraan yang dilakukan (Tjokroamidjojo, 2000). Pertanggungjawaban merupakan wujud konsekuensi penyelenggaraan pemerintahan dalam pengelolaan dana desa kepada pihak-pihak terkait. Dalam hal ini, Pemerintah Desa wajib membuat laporan pengelolaan dana desa. Penyampaian Laporan Realisasi Dana Desa secara tertulis oleh Pemerintah Desa Cepogo kepada Bupati Boyolali. Dalam tata kelola pemerintahan yang baik (good government governance), maka pertanggungjawaban tersebut tidak hanya disampaikan kepada pemerintah pada tingkat yang lebih tinggi saja, tetapi laporan tersebut juga harus disampaikan kepada masyarakat. Berikut uraian pertanggungjawaban yang dilakukan oleh pemerintah desa:

"Ada, website ada, itu untuk umum. Tapi tidak terperinci seperti dalam laporan SPJ, tapi sampai rinci, katakanlah mungkin itu, tidak diperbolehkan” (Informan 4, Staf Administrasi).

"Kalau peraturan desa itu yang realisasi APBDes, kalau realisasi dana desa itu tidak diperdeskan. Kan sudah include di APBDes tadi. Tapi ada laporan tersendiri tentang dana desa itu ada" (Informan 2, Sekretaris Desa).

Pertanggungjawaban pengelola dana desa kepada masyarakat, yakni dalam bentuk fisik dan juga musyawarah atau rapat pertanggungjawaban pelaksanaan dana desa yang dihadiri oleh BPD selaku wakil dari masyarakat desa. Berikut hasil wawancara sebagai berikut:

"Pertanggungjawaban pelaksana ADD kepada masyarakat, yaitu dalam bentuk fisik yang telah disepakati di dalam musrenbangdes dan rapat pertanggungjawaban ADD" (Informan 2, Sekretaris Desa).

Di sisi lain, pengelolaan administrasi keuangan sebagaimana hasil wawancara dengan informan diperoleh informasi sebagai berikut: 
"Pengelolaan administrasi keuangan disertai dengan bukti pendukung berupa nota dan kwitansi ditambah surat pesanan dan surat perintah kerja dari kepala desa untuk pesanan material (CV atau toko bangunan) untuk kegiatan fisik" (Informan 3, Bendahara Desa).

Informasi-informasi tersebut menunjukkan bahwa sistem pertanggungjawaban pelaksanaan dana desa di Desa Cepogo telah melaksanakan prinsip akuntabilitas. Pengelola dana desa juga telah melaksanakan pertanggungjawaban administrasi keuangan dana desa dengan baik yaitu setiap pembelanjaan yang bersumber dari dana desa harus disertai dengan bukti. Hal tersebut didukung dengan informasi yang diperoleh dari informan sebagai berikut:

"Dalam mengeluarkan uang yang bersumber dari ADD harus disertai dengan bukti pendukung berupa nota dan kwitansi dan juga tanda terima" (Informan 3, Bendahara Desa).

Dari kutipan wawancara tersebut menunjukkan bahwa selama dalam pelaksanaan dana desa tetap dituntut pertanggungjawaban di setiap pembelanjaan uang dana desa. Dengan demikian apabila hal tersebut telah dilakukan secara terus menerus, tertib dan sesuai dengan ketentuan yang ada, maka akan dapat meringankan/mendukung penyusunan pertanggungjawaban akhir kegiatan dana desa yang nantinya akan disusun oleh Tim Pelaksanan Desa, sedangkan pemahaman pengelolaan administrasi keuangan dana desa dapat diketahui dari hasil wawancara sebagai berikut:

"Pelaksana ADD sudah memahami tentang pengelolaan administrasi keuangan Dana Desa sesuai dengan sosialisasi dan petunjuk dari pemerintah kabupaten dan juga petunjuk dari buku pedoman pelaksanaan bantuan keuangan kepada pemerintah desa" (Informan 3, Bendahara Desa).

Dari hasil wawancara tersebut dapat, pelaksana dana desa dapat memahami dan mengerti tentang tata kelola administrasi keuangan dana desa, karena selalu ada petunjuk dari pemerintah kabupaten. Dari sisi akuntabilitas, pelaksanaan dana desa di Desa Cepogo telah memenuhi prinsip akuntabilitas seperti disampaikan oleh Tjokroamidjojo (2000), yaitu tanggung gugat dari pengurusan atau penyelenggaraan yang dilakukan. Hal ini didukung penerapan di lapangan yang menunjukkan bahwa semua uang yang telah dikeluarkan dapat dipertanggungjawabkan secara fisik dan administrasi keuangan. Pertanggungjawaban dana desa dari sisi fisik di semua desa dapat dikatakan berhasil dengan baik dan sudah selesai sepenuhnya.

\section{Akuntabilitas}

Akuntabilitas sistem pengelolaan dana desa ini dimaksudkan sebagai upaya untuk mewujudkan tata kelola pemerintahan yang baik (good governance). Dana desa harus dilaksanakan secara terbuka melalui musyawarah desa dan hasilnya dituangkan dalam bentuk Peraturan Desa (Perdes). Ketentuan tersebut menunjukkan adanya komitmen dari para stakeholder/pengambil keputusan bahwa pengelolaan dana desa itu harus memenuhi prinsip-prinsip good governance yang harus dilaksanakan oleh para pengelola dana desa dan juga masyarakatnya. Adanya komitmen yang kuat dari Pemerintah Desa Cepogo untuk meningkatkan partisipasi masyarakat, sesuai dengan informasi wawancara sebagai berikut:

“Ada pun komitmen dari Pemerintah Desa Cepogo agar lebih mempercepat dinamika pembangunan, yaitu dengan cara untuk menggali swadaya masyarakat. 
Artinya, pemerintah desa berupaya dengan jumlah dana desa yang relatif kecil ini mengajak masyarakat ikut serta di dalam mempercepat pembangunan desa"

(Informan 1, Kepala Desa).

Pendapat informan tersebut memberi sinyal bahwa dalam menumbuhkan partisipasi masyarakat desa khusunya dalam pengelolaan dana desa harus dilaksanakan secara bersama-sama oleh semua stakeholders dalam menyelesaikan semua permasalahan yang ada di desa. Pelaksanaan tersebut dalam rangka penerapan prinsip partisipatif pembangunan masyarakat desa yang didukung oleh prinsip-prinsip transparan dan akuntabel.

\section{Transparansi}

Prinsip untuk menjamin kebebasan bagi setiap orang untuk dapat memperoleh informasi tentang penyelenggaraan pemerintahan adalah transparansi. Informasi yang berhak diperoleh masyarakat baik dari tahapan proses perencanaan, pelaksanaan, dan pertanggungjawaban. Pelaporan dibangun atas dasarkebebasan memperoleh informasi. Informasi yang berkaitan dengan kepentingan publik secara langsung dapat diperoleh oleh mereka yang membutuhkan. Pemerintah Desa Cepogo memberikan informasi terkait dengan penyelenggaraan pemerintahan sebagai berikut:

"[...] setelah paska itu kita buat seperti ini, IPKD (Informasi Penyelenggaraan Kepala Desa). Jadi kita, tahun yang berkenaan kita buat grafik seperti ini (di koran). Ditempelkan di tempat umum. Ini transparansinya" (Informan 4, Staf Administrasi).

"Jadi sekarang online, misalnya online itu server di kabupaten tetap tahu desa A, $B, C$ online. Jadi ini masukkan ini keluar SPP, pengeluaran ini tahu semua. Itu juga salah satu bentuk transparansi" (Informan 3, Keuangan Desa).

"Ada, wibsite ada, itu untuk umum. Tapi tidak terperinci seperti dalam laporan SPJ, tapi sampai rinci, katakanlah mungkin itu, tidak diperbolehkan" (Informan 4, Staf Administrasi).

Berdasarkan uraian dari Informan 3 dan 4, Transparansi yang dibangun oleh Pemerintah Desa Cepogo menempatkan dokumen desa sebagai dokumen publik, kecuali dokumen data kependudukan dan data aset warga desa. Informasi-informasi mengenai penyelenggaraan pemerintahan disampaikan melalui situs web Desa Cepogo, papan pengumuman di kantor desa, dan penyampaian informasi juga melalui perwakilan tiap-tiap Kepala Dusun dan Ketua RT. Perangkat desa juga mengelola website desa. Selain itu, laporan realisasi pelaksanaan APBDesa juga dipublikasikan melalui koran.

"Jadi kita, tahun yang berkenaan kita buat grafik seperti ini (di koran). Ditempelkan di tempat umum. Ini transparansinya” (Informan 4, Staf Administrasi).

“Ada, website ada, itu untuk umum” (Informan 4, Staf Administrasi).

"Ya kan ada ini laporan realisasi yang dimuat di koran, lalu dibagikan kepada masyarakat ini secara umum. Kalau pertangungjawaban itu setiap akhir masa jabatan akan ada LPPD dan itu dilaporkan kepada Bupati" (Informan 2, Sekretaris Desa).

Upaya komunikasi melalui berbagai media yang dilakukan oleh Pemerintah Desa Cepogo agar masyarakat memperoleh informasi tentang penyelenggaraan pemerintahan. Suatu komunikasi dapat dikatakan efektif apabila sasaran maupun tujuan komunikasi 
dapat tercapai. Berikut merupakan penjelasan dari beberapa informan mengenai keefektifan pemerintah desa dalam hal transparansi:

"Kalau masyarakat berhak menanyakan atau berhak bertanya salah satunya melalui Badan Permusyawaratan Desa" (Informan 2, Sekretaris Desa).

"Masyarakat itu ngerti misalya disini ada selokan panjangnya sekian meter, dalamnya sekian meter, ini sudah diukur semua sehingga pada saat masyarakat akan usul, eh tempat saya butuh selokan dibenahi, kita sudah tahu datanya sudah ada. Kemudian akan kita laksanakan sesuai dengan kebutuhan" (Informan 1, Kepala Desa).

“....bagi yang tahu IT, tapi ya kita sekali lagi salah satu upaya kita untuk membuat transparasi. Yang lainnya ya itu kita sampaikan tadi, dengan hardcopy atau bisa tanya langsung ke kantor" (Informan 4, Staf Administrasi).

Teknologi di era globalisasi yang sangat pesat ini masyarakat dengan mudah dapat mengakses informasi yang disediakan oleh pemerintah desa di situs website, yaitu masyarakat yang berusia 26-35 tahun. Selain itu, untuk masyarakat yang belum mengenal teknologi seperti masyarakat yang berusia lebih dari 65 tahun bisa melihat di media cetak atau koran. Transparansi yang dilakukan oleh pemerintah desa dirasa sudah efektif dengan menggunakan situs website dan media cetak. Situs web dirasa paling efektif untuk pihak di luar masyarakat, seperti mahasiswa yang berkeinginan untuk melihat penyelenggaraan pemerintah desa dan pihak investor untuk melihat potensi yang ada di desa Cepogo. Namun, Pemerintah Desa Cepogo tetap berusaha melakukan transparasi pelaporan kepada semua pihak. Pelaporan itu dilakukan pemerintah dengan memberikan informasi penyelenggaraan pemerintahan kepada Kepala Dusun maupun Ketua RT/RW, serta membuat pengumuman di kantor desa, sehingga masyarakat yang belum paham akan teknologi dapat memperoleh informasi.

\section{KESIMPULAN DAN SARAN}

Hasil penelitian tentang penerapan prinsip tranparansi dan akuntabilitas pengelolaan dana desa yang dilakukan oleh Pemerintah Desa Cepogo, Kecamatan Cepogo, Kabupaten Boyolali, Provinsi Jawa Tengah menunjukkan bahwa tahap perencanaan telah menerapkan prinsip partisipasi dan transparansi. Hal ini dibuktikan dengan kehadiran masyarakat yang sangat antusias dalam forum musyawarah desa atau Musyawarah Rencana Pembangunan Desa (Musrenbangdes). Selain itu, dalam musyawarah desa tersebut, pemerintah desa terbuka untuk menerima segala usulan masyarakat agar pembangunan Desa Cepogo dapat berjalan lancar melalui tata kelola pemerintahan yang baik atau good government governance.

Tahap pelaksanaan program pembangunan di Desa Cepogo telah menerapkan prinsip transparansi dan akuntabilitas. Prinsip transparansi terpenuhi dengan adanya informasi yang jelas melalui website dan surat kabar berkaitan dengan jadwal pelaksanaan pembangunan fisik yang dibiayai dengan dana desa. Prinsip akuntabilitas telah terlaksana sepenuhnya, karena pertanggungjawaban secara fisik dan administrasinya sudah diselesaikan secara lengkap, serta memenuhi prinsip-prinsip good governance.

Tahap penatausahaan dalam pengelolaan dana desa, Pemerintah Desa Cepogo sudah melaksanakannya dengan baik. Hal itu dibuktikan oleh bendahara yang melaku- 
kan pencatatan penerimaan dan pengeluaran secara tertib. Setiap bulan, bendahara melakukan tutup buku dan membuat laporan periodik yang disampaikan kepada Kepala Desa Cepogo. Tahap pelaporan dan pertanggungjawaban menunjukkan proses pertanggungjawaban Kepala Desa Cepogo yang disampaikan tepat waktu kepada Camat Cepogo maupun Bupati Boyolali melalui penyampaian Laporan Realisasi Pengelolaan Dana Desa. Selain itu, pertanggungjawaban juga dilakukan kepada masyarakat melalui kegiatan musyawarah desa. Pengawasan pengelolaan keuangan desa dilakukan oleh BPD sebagai pengawas dan berfungsi untuk menetapkan peraturan desa (Perdes) bersama Kepala Desa yang sudah berjalan dengan baik. Pengawasan oleh BPD terhadap pengelolaan keuangan desa telah dilaksanakan semaksimal mungkin sesuai tugas pokok dan fungsi BPD.

\section{DAFTAR REFERENSI}

Arifiyanto, D. F., \& Kurrohman, T. (2014). Akuntabilitas Pengelolaan Alokasi Dana Desa di Kabupaten Jember. Jurnal Riset Akuntansi dan Keuangan, 2(3), 473-485.

Astuti, T. P., \& Yulianto, Y. (2016). Good Governance Pengelolaan Keuangan Desa Menyongsong Berlakunya Undang-Undang Nomor 6 Tahun 2014. Jurnal Riset Akuntansi, 1(1), 1-14.

Coryanata, I. (2012). Akuntabilitas, Partisipasi Masyarakat dan Transparansi Kebijakan Publik sebagai Pemoderating Hubungan Pengetahuan Dewan tentang Anggaran dan Pengawasan Keuangan Daerah (APBD). Jurnal Akuntansi dan Investasi, 12(2), 110-125.

DPR RI (2014). Undang-Undang Nomor 6 Tahun 2014 tentang Desa. Diakses tanggal 24 Oktober 2019 dari https://www.dpr.go.id/dokjdih/document/uu/UU_2014_6.pdf.

DPR RI (2019). Pengelolaan Dana Desa Masih Bermasalah. Diakses tanggal 23 November 2019 dari http://www.dpr.go.id/berita/detail/id/25283/t/Pengelolaan+Dana+Desa+Masih+Be rmasalah.

Farida, V., Jati, W. A., \& Harventy R., (2018). Analisis Akuntabilitas Pengelolaan Alokasi Dana Desa (ADD) di Kecamatan Candipuro Kabupaten Lumajang. Jurnal Akademi Akuntansi, 1(1), 64-73.

Ismail, M., Widagdo, A.K., \& Widodo, A. (2016). Sistem Akuntansi Pengelolaan Dana Desa. Jurnal Ekonomi dan Bisnis, 19(2), 329-339.

Jensen, C. M., \& Meckling, W. H. (1976). Theory of the Firm: Managerial Behaviour, Agency Costs, and Ownership Structure. Journal of Financial Economics, 3, 305360.

Kemenkeu (2015). Peraturan Pemerintah RI No 22 Tahun 2015 tentang Perubahan atas Pertaruran Pemerntah No 60 tahun 2014 tentang Dana Desa yang Bersumber dari APBN. Diakses tanggal 2 November 2019 dari https://jdih.kemenkeu.go.id/fullText/2015/22TAHUN2015PP.pdf.

Kemenkeu (2017). Buku Saku Dana Desa. Diakses tanggal 19 Oktober 2019 dari http://www.djpk.kemenkeu.go.id/wp-content/uploads/2017/12/Buku-Saku-DanaDesa-ttd-menteri-final-cover_opt.pdf. 
Kemendagri (2007). Peraturan Menteri Dalam Negeri Nomor 37 tahun 2007 tentang Pedoman Pengelolaan Keuangan Desa. Diakses tanggal 20 Oktober 2019 dari https://www.google.com/url?sa $=\mathrm{t} \& \mathrm{rct}=\mathrm{j} \& \mathrm{q}=\& \mathrm{esrc}=\mathrm{s} \&$ source $=$ web $\& \mathrm{~cd}=\& \mathrm{ved}=2 \mathrm{a}$ hUKEwiDr4Hc7LzqAhXET30KHaZ4CcEQFjAAegQIBhAB\&url=http\%3A\%2F $\% 2$ Fbinapemdes.kemendagri.go.id\%2Fuploads\%2Fgallery\%2FPermendagri_No. 37_Th_._2007_Ttg_._Pedoman_Pengelolaan_Keuangan_Desa_.pdf\&usg=AOvV aw0J_pLLkQp-CpTSXVcdKxAw.

Krina, P. L. L. (2003). Indikator dan Alat Ukur Prinsip Akuntabilitas, Transparansi dan Partisipasi. Jakarta: Bappenas.

LAN \& BPKP (2000). Akuntabilitas dan Good Governance. Bogor. Diakses tanggal 21 Desember 2019 dari http://kms.ipb.ac.id/1715/1/Akuntabilitas\%20dan\%20Good\%20Governance\%2C $\% 20$ Modul\%201\%20dari\%205\%20Modul\%20Sosialisasi\%20Sistem\%20Akuntab ilitas\%20Kinerja\%20Instansi\%20Pemerintah\%20\%28AKIP\%29.pdf.

Moleong, L. J. (2012). Metodologi Penelitian Kualitatif. Bandung: PT Remaja Rosdakarya.

Pemerintah Desa Panggungharjo (2014). Permendagri No. 113 Tahun 2014 tentang Pengelolaan Keuangan Desa. Diakses tanggal 26 Oktober 2019 dari http://www.panggungharjo.desa.id/wpcontent/uploads/2018/02/PERMENDAGRI-No.-113-Tahun-2014-tentangPengelolaan-Keuangan-Desa.pdf.

Putra, H. S. (2017). Tata Kelola Pemerintahan Desa dalam Mewujudkan Good Governace di Desa Kalibelo Kabupaten Kediri. Jurnal Politik Muda, 6(2), 110119.

Putra, I. P. A. S., Sinarwati, K., \& Wahyuni, M. A. (2017). Akuntabilitas dan Transparansi Pengelolaan Alokasi Dana Desa (ADD) di Desa Bubunan Kecamatan Seririt Kabupaten Buleleng. e-Journal Universitas Pendidikan Ganesha, 8(2), 1-11.

Rahadian, A. H. (2010). Mewujudkan Good Governance melalui Pelayanan Publik. Jurnal Ilmiah STIAMI, 57-70.

Rahum, A. (2015). Pengelolaan Alokasi Dana Desa (ADD) dalam Pembangunan Fisik Desa Krayan Makmur Kecamatan Long Ikis Kabupaten Paser. E-journal Ilmu Pemerintahan, 3(4), 97-113.

Tjokroamidjojo, B. (2000). Good Governance (Paradigma Baru Manajemen Pembangunan). Jakarta: UI Press.

Tomuka, S. (2015). Penerapan Prinsip-Prinsip Good Governance dalam Pelayanan Publik di Kecamatan Girian Kota Bitung (Studi tentang Pelayanan Akte Jual Beli). E-journal Unsrat, 2(2), 1-15.

United Nations Development Program (UNDP) (1997). Governance for sustainable human development. Diakses tanggal 24 November 2019 dari http://OpeningDiscussion-Paper--Governance-for-Sustainable-Development.pdf.

Widayanti, R., Masitoh, E., \& Dwi, A. (2019). Penerapan Azas Pengelolaan Keuangan Desa: Tinjauan Permendagri Nomor 113 Tahun 2014 di Wilayah Wonogiri Jawa Tengah. Jurnal FEB UNMUL Kinerja, 16(1), 10-21. 